\title{
Growth and puberty in a prospective cohort of patients with sickle-cell anaemia: an assessment over ten years
}

\author{
Ingrid Cristiane Pereira Gomes ${ }^{1}$, Hugo Nivaldo Melo', Suyaluane Italla Amana Melo1, \\ Nelmo Vasconcelos de Menezes ${ }^{1}$, Tulio Vinicius Paes Dantas ${ }^{2}$, Rosana Cipolotti ${ }^{1}$
}

Doi: http://dx.doi.org/10.7322/jhgd.127681

\begin{abstract}
Introduction: Hereditary haemoglobinopathies are the most common group of monogenic hereditary diseases in the world. Erythrocytes in sickle form, cellular expression of polymerization of deoxygenated $\mathrm{HbS}$, cause intermittent vascular obstruction, leading to tissue ischaemia and consequent chronic damage in organs and endocrine glands.
\end{abstract}

Objective: The evaluation of the growth pattern and pubertal development of a group of patients with sickle-cell anaemia from childhood to adulthood.

Methods: Thirty patients withsickle-cell anaemia between the ages of 10 and 23 years were evaluated in a prospective longitudinal study at three points in time (Te1: 2005; Te2: 2010 and Te3: 2015) and compared with controls. Anthropometric, pubertal and hormonal evaluations were carried out. Age- and gender-specific Z-scores for weight, height and body mass index were calculated according to the reference growth standards.

Results: Thirty patients with sickle-cell anaemia (mean age $=13.93$ years) were evaluated at $\mathrm{Te} 1$ and 26 patients (meanage $=25.08$ years)atTe3. Thesickle-cellanaemiagrouplowershowedZ-scoresforweight $(p=0.0002)$, height $(p=0.0184)$ and body mass index $(p=0.0011)$ than the control group at Te1. At Te3, there was no difference in height, but weight $(p=<0.0001)$ and body mass index $(p=<0.0001)$ were lower in the sickle-cell anaemia group. Men showed greater weight commitment than women at the three study times (Te1: $p=$ 0.0340 , Te2: $p=0.0426$ and Te3: $p=0.0387)$ and lower body mass index in Te3 $(p=0.0155)$ in the sicklecell anaemia group. There was a significant increase in weight when comparing Te1 with Te3 $(p=0.0009)$ and in height when comparing Te1 with Te2 $(p=0.0292)$ and with Te3 $(p=0.0003)$ in the sickle-cell anaemia group. There was a significant increase in weight when comparing Te1 and Te3 $(p=0.0009)$ and in height when comparing Te1 and Te2 $(p=0.0292)$ and Te3 $(p=0.0003)$ in the sickle-cell anaemia group. At Te1, 14 cases and 2 controls were prepubertal. Bone age was delayed in 12 patients. Age at menarche was delayed and lower in the sickle-cell anaemia group (mean $=15$ years). Five patients had gestated, but no patient had experienced fatherhood. At Te1, TSH levels were higher $(p=0.0080)$ and T3 levels were lower $(p=0.0020)$ in the sickle-cell anaemia group. At Te3, LH and FSH levels were higher in men with sickle-cell anaemia $(p=0.0014 ; p ; 0.0002)$. IGF-I levels were lower in cases both at Te1 $(p=0.0002)$ and at Te3 $(p=$ 0.0032).

Conclusion: Patients with sickle-cell anaemia showed growth impairment and pubertal delay compared with healthy controls. However, albeit belatedly, they reached normal sexual maturation and height in adulthood. Women with sickle-cell anaemia showed no fertility problems. The findings highlight the need to investigate the intention of paternity and fertility among men with sickle-cell anaemia.

Keywords: sickle-cell anaemia, prospective cohort, growth, puberty.

\section{INTRODUCTION}

Hereditary haemoglobinopathies are the most common group of monogenic hereditary diseases in the world. Among these, sickle-cell disease affects more than
300,000 newborns every year, most of whom live in underdeveloped countries or in areas or families with a low socio-economic level in emerging countries. Furthermore, over $70 \%$ of newborns are homozygous for atypical haemoglobin, haemoglobin S, which characterizes sickle-cell

\footnotetext{
1 Universidade Federal de Sergipe, Brasil.

2 Universidade Federal Rural de Pernambuco, Brasil

Corresponding author: Rosana Cipolotti - E-mail: rosanaci@yahoo.com
}

Suggested citation: Gomes ICP, Melo HI, Melo SIA, Menezes NV, Dantas TVP, Cipolotti R. Growth and puberty in a prospective cohort of patients with sickle-cell anaemia: an assessment over ten years. J Hum Growth Dev. 2017; 7(1): 91-98. Doi: http://dx.doi.org/10.7322/jhgd.127681 Manuscript submitted 2016, accepted for publication Jun 2016. 
anaemia, representing the most severe form of $\mathrm{SCD}^{1}$. Erythrocytes in sickle form, cellular expression of polymerization of deoxygenated haemoglobin S, cause intermittent vascular obstruction, leading to tissue ischaemia and consequent chronic damage in organs and endocrine glands ${ }^{2}$.

Delayed growth and puberty in children and adolescents are among the endocrine complications in sickle-cell anaemia and have been reported previously ${ }^{3,4}$. Most available data refers to cross-sectional observations ${ }^{5,6}$, except for studies from a Jamaican cohort that evaluated growth and puberty in individuals from birth to adulthood. Studies on the persistence of impaired stature and on possible repercussions of restricted growth and pubertal delay in adults with sickle-cell anaemia are controversial ${ }^{7,8}$.

Due to the lack of prospective longitudinal observations on growth and puberty in sickle-cell anaemia in the Brazilian population, the objective is to analyse the pattern of growth and pubertal development of a group of patients with sickle-cell anaemia from childhood to adulthood.

\section{METHODS}

\section{Study design}

A prospective longitudinal study was conducted in patients with sickle-cell anaemia attending the outpatient Paediatric Haematology service of the University Hospital of the Federal University of Sergipe, the university centre of regional reference in Aracaju, the capital city of Sergipe in the north-east of Brazil. Data were collected in the period from July 2005 to November 2015. The patients underwent anthropometric measurements at three points in time (Te1: in 2005, Te2: in 2010 and Te3: in 2015) and hormonal evaluation at $\mathrm{Te} 1$ and $\mathrm{Te} 3$.

\section{Study population}

The sample was selected during days of routine outpatient visits. A total of 30 patients with sickle-cell anaemia confirmed by haemoglobin electrophoresis, aged from nine years for boys and eight years for girls, were enrolled at Te1. These patients had no clinical complication at the time of data collection and had not received blood products in the previous three months. They had not used steroid medications or other hormones in the last 30 days and had no chronic disease unrelated to sickle-cell anaemia that could interfere with their height and weight development and/or puberty. Healthy individuals, matched for age and sex, were recruited from various municipalities in the state of Sergipe to make up the control groups at Te1 $(n=30)$ and Te3 $(n=35)$. The controls underwent haemoglobin electrophoresis and any patients with sickle-cell trait or any haemoglobinopathy were excluded. Any other inclusion criteria were equally applied to patients and to the controls.

\section{Growth and pubertal development evaluation}

Weight was assessed using a digital scale (Leader) and height was assessed using a vertical stadiometer (Tonelli) applying standard techniques. Body mass index (BMI) was calculated using the formula BMI $=$ weight $/(\text { height })^{2}$ and expressed in $\mathrm{kg} / \mathrm{m}^{2}$. Age- and gender-specific Z-scores for weight were calculated according to the Centre for Disease Control and Prevention (CDC) reference growth standards, 2000', whilst age- and gender-specific Z-scores for height and BMI were calculated according to the World Health Organization (WHO) reference growth standards, $2007^{10}$. Anthropometric assessment was carried out in the three phases of the study.

Pubertal stage was assessed according to Marshall and Tanner ${ }^{11,12}$ and the patients were classified as prepubertal when they were in Tanner stage 1 and as pubertal when they were in Tanner stages 2 to 5 . Bone age was assessed according to Greulich and Pyle ${ }^{13}$ and was considered delayed when two years below the chronological age. Women or guardians were directly questioned about their age at menarche at Te1 and Te3. Women were interrogated about their obstetric history and men were interrogated about their number of children in Te3.

\section{Laboratory evaluation}

Triiodothyronine (T3), free thyroxine (FT4), thyroid stimulating hormone (TSH), follicle stimulating hormone (FSH), luteinizing hormone (LH), prolactin (PRL) and estradiol (E2) in females and testosterone (T) in men and somatomedin $\mathrm{C}$ (IGF-1) were measured in cases and controls. TSH, PRL, LH and FSH were measured by immunoradiometric assay, T3, FT4, T and E2 by fluoroimmunoassay, and IGF-I by immunoradiometric assay. The dosages measured at Te1 were also measured at Te 3 in cases and controls, all by chemiluminescence method. The assays were performed at the Clinical Laboratory of the University Hospital of the Federal University of Sergipe.

Informed consent was obtained from the participants or from the parent or guardian if the participants were younger than 18 years old. This study was approved by the Ethical Committee of Human Beings of Human Studies of the Federal University of Sergipe on August 14, 2003.

\section{Statistical analysis}

The results were described as absolute numbers and percentages (categorical variables) and mean \pm standard deviation (continuous variables). The Mann-Whitney test for independent samples was used to assess comparisons between groups of cases versus controls and between the genders within the sickle-cell anaemia group. In order to compare the means, ANOVA using the Kruskal-Wallis test followed by the Student-Newman-Keuls test was used to assess comparisons between $\mathrm{Te} 1, \mathrm{Te} 2$ and $\mathrm{Te} 3$ (case group). Differences were considered significant if $P$-values were $<0.05$.

\section{RESULTS}

Thirty patients with sickle-cell anaemia, 16 boys $(53.3 \%)$ and 14 girls (46.7\%), with a mean age of 13.93 years were evaluated at baseline (Te1). The mean age and proportion of boys and girls were similar in both groups (sickle-cell anaemia and control group). The sample was 
reduced to 26 patients (four patients died and one patient was no longer monitored) at Te3, but the mean age remained similar to that of the control group in this time (c.f. Table 1).

The weight, height and BMI of patients with sickle-cell anaemia showed statistically significant differences compared with the control group at Te1. At Te3, no significant difference in height was observed, however weight and BMI were significantly lower in the group with sickle-cell anaemia than in the control group (c.f. Table 1).

Men from the sickle-cell anaemia group had significantly lower weight and BMI than men from the control

Table 1: Anthropometric data of patients with sickle cell anaemia (Cases) in the three study times compared to their healthy controls (Controls)

\begin{tabular}{|c|c|c|c|c|c|c|}
\hline & STUDY TIMES & $\begin{array}{c}{ }^{*} \text { CASES MEAN } \\
\text { MEAN } \pm \text { SD }\end{array}$ & RANGE & $\begin{array}{l}{ }^{* *} \text { CONTROLS } \\
\text { MEAN } \pm \text { SD }\end{array}$ & RANGE & $\mathbf{p}$ \\
\hline \multirow[t]{3}{*}{ Age (years) } & Te1 & $13.93 \pm 3.35$ & 10 a 23 & $14.4 \pm 2.63$ & 9 a 19 & 0.3516 \\
\hline & $\mathrm{Te} 2$ & $20.07 \pm 3.25$ & 16 a 29 & & & \\
\hline & Te3 & $25.08 \pm 2.80$ & 20 a 33 & $25.4 \pm 2.84$ & 21 a 34 & 0.7483 \\
\hline Weight for age & Te1 & $-1.46 \pm 0.56$ & $-2.41 \mathrm{a}-0.12$ & $-0.54 \pm 1.11$ & -2.04 a 2.68 & $0.0002^{*}$ \\
\hline \multirow[t]{2}{*}{ Z-score } & $\mathrm{Te} 2$ & $-1.14 \pm 0.72$ & -2.26 a 0.25 & & & \\
\hline & $\mathrm{Te} 3$ & $-0.86 \pm 0.62$ & -1.68 a 0.42 & $0.18 \pm 0.80$ & -1.20 a 2.26 & $<0.0001^{*}$ \\
\hline Height for age & Te1 & $-1.44 \pm 1.17$ & -3.50 a 1.32 & $-0.57 \pm 1.57$ & -3.93 a 2.85 & $0.0184^{*}$ \\
\hline \multirow[t]{2}{*}{ Z-score } & $\mathrm{Te} 2$ & $-0,61 \pm 0,96$ & $-2,30$ a 1,43 & & & \\
\hline & $\mathrm{Te} 3$ & $-0.41 \pm 1.03$ & -2.70 a 1.73 & $-0.19 \pm 0.85$ & -1.58 a 1.78 & 0.6149 \\
\hline BMI for age & Te1 & $-1.53 \pm 1.38$ & -5.50 a 0.34 & $-0.34 \pm 1.19$ & -2.73 a 2.56 & $0.0011^{*}$ \\
\hline \multirow[t]{2}{*}{ Z-score } & $\mathrm{Te} 2$ & $-1.35 \pm 1.38$ & -3.37 a 1.28 & & & \\
\hline & Te3 & $-0.65 \pm 1.01$ & -2.29 a 2.10 & $0.63 \pm 0.99$ & -1.94 a 2.71 & $<0.0001^{*}$ \\
\hline
\end{tabular}

Study times: Te1: 2005; Te2: 2010; Te3: 2015.

* Number of cases $(n):$ Te1 $n=30 ; T 2 n=29$. Except weight $n=24$. height and BMI $n=23 ; T 3 n=26$. Except weight and BMI $n=25$ (pregnant patient excluded).

** Number of controls $(n):$ Te1 age $n=30$. Other variables: $n=29 ;$ Te2: There was no control group; Te3: $n=35$.

* Statistically significant difference.

SD: Standard deviation.

Table 2: Anthropometric data of patients with sickle cell anaemia (cases) in the three study times compared to their healthy controls (controls) by gender

\begin{tabular}{|c|c|c|c|c|c|c|c|}
\hline & \multicolumn{4}{|c|}{ MALE } & \multicolumn{3}{|c|}{ FEMALE } \\
\hline & STUDY TIMES & $\begin{array}{c}{ }^{*} \text { CASES } \\
\text { MEAN } \pm \text { SD }\end{array}$ & $\begin{array}{c}{ }^{* *} \text { CONTROLS } \\
\text { MEAN } \pm \text { SD }\end{array}$ & $\mathbf{p}$ & $\begin{array}{c}{ }^{*} \text { CASES } \\
\text { MEAN } \pm \text { SD }\end{array}$ & $\begin{array}{c}{ }^{* *} \text { CONTROLS } \\
\text { MEAN } \pm \text { SD }\end{array}$ & $p$ \\
\hline \multirow{4}{*}{ Age (years) } & Te1 & $14.25 \pm 3.29$ & $14.50 \pm 2.42$ & 0.4397 & $13.57 \pm 3.50$ & $13.85 \pm 2.90$ & 0.5351 \\
\hline & Te2 & $20.13 \pm 1.07$ & & & $20.00 \pm 3.55$ & & \\
\hline & Te3 & $24.77 \pm 2.28$ & $24.80 \pm 2.59$ & 0.8178 & $25.38 \pm 3.30$ & $25.85 \pm 3.00$ & 0.3866 \\
\hline & Te1 & $34.83 \pm 9.14$ & $48.13 \pm 17.16$ & $0.0063^{*}$ & $36.00 \pm 12.72$ & $45.18 \pm 12.00$ & 0.0523 \\
\hline \multirow[t]{2}{*}{ Weight (kg) } & $\mathrm{Te} 2$ & $53.36 \pm 8.82$ & & & $49.12 \pm 7.87$ & & \\
\hline & Te3 & $58.98 \pm 7.23$ & $77.20 \pm 10.13$ & $0.0001^{*}$ & $53.79 \pm 7.14$ & $61.30 \pm 8.86$ & $0.0265^{*}$ \\
\hline \multirow{4}{*}{$\begin{array}{l}\text { Weight for } \\
\text { age Z-score }\end{array}$} & Te1 & $-1.69 \pm 0.40$ & $-0.30 \pm 0.59$ & $<0.0001^{*}$ & $-1.20 \pm 0.61$ & $-0.71 \pm 1.36$ & 0.5649 \\
\hline & Te2 & $-1.39 \pm 0.72$ & & & $-0.86 \pm 0.64$ & & \\
\hline & Te3 & $-1.08 \pm 0.59$ & $0.41 \pm 0.83$ & $0.0001^{*}$ & $-0.62 \pm 0.60$ & $0.008 \pm 0.74$ & $0.0265^{*}$ \\
\hline & Te1 & $147.53 \pm 13.98$ & $155.80 \pm 12.24$ & 0.0595 & $144.60 \pm 14.48$ & $153.84 \pm 10.20$ & 0.0584 \\
\hline \multirow[t]{2}{*}{ Height $(\mathrm{cm})$} & Te2 & $171.03 \pm 6.65$ & & & $159.25 \pm 7.83$ & & \\
\hline & Te3 & $173.90 \pm 6.26$ & $175.52 \pm 7.15$ & 0.9083 & $160.07 \pm 7.95$ & $161.58 \pm 4.94$ & 0.6060 \\
\hline \multirow{4}{*}{$\begin{array}{l}\text { Height for age } \\
\text { Z-score }\end{array}$} & Te1 & $-1.66 \pm 1.21$ & $-0.65 \pm 1.47$ & 0.0512 & $-1.20 \pm 1.13$ & $-0.34 \pm 1.64$ & 0.1036 \\
\hline & Te2 & $-0.65 \pm 0.80$ & & & $-0.57 \pm 1.17$ & & \\
\hline & Te3 & $-0.36 \pm 0.86$ & $-0.14 \pm 0.98$ & 0.9265 & $-0.46 \pm 1.22$ & $-0.24 \pm 0.75$ & 0.6189 \\
\hline & Te1 & $15.85 \pm 2.54$ & $19.16 \pm 3.35$ & $0.0093^{*}$ & $16.72 \pm 3.03$ & $19.01 \pm 4.22$ & 0.1530 \\
\hline \multirow[t]{2}{*}{ BMI $\left(\mathrm{Kg} / \mathrm{m}^{2}\right)$} & Te2 & $18.22 \pm 2.74$ & & & $19.21 \pm 3.20$ & & \\
\hline & Te3 & $19.47 \pm 1.77$ & $25.14 \pm 3.60$ & $0.0001^{*}$ & $21.40 \pm 3.53$ & $23.51 \pm 3.50$ & 0.0565 \\
\hline BMI for age & Te1 & $-1.85 \pm 1.30$ & $-0.15 \pm 1.12$ & $0.0017^{*}$ & $-1.16 \pm 1.43$ & $-0.47 \pm 1.25$ & 0.3508 \\
\hline \multirow[t]{2}{*}{ Z-score } & Te2 & $-1.69 \pm 1.32$ & & & $-0.92 \pm 1.37$ & & \\
\hline & Te3 & $-1.12 \pm 0.78$ & $0.80 \pm 0.99$ & $0.0001^{*}$ & $-0.14 \pm 1.01$ & $0.50 \pm 1.00$ & $0.0446^{*}$ \\
\hline
\end{tabular}

Study times: Te1: 2005; Te2: 2010; Te3: 2015

* Number of cases $(n)$ : male: Te1 $n=16 ;$ Te2 $n=15 ;$ Te3 $n=13$; female: Te1 $n=14 ;$ Te2 $n=14 ;$ Te3 $n=13$. Except weight. BMI and their Z-scores $n=12$ (pregnant patient excluded).

** Number of controls $(n)$ : male: Te1 $n=16 ;$ Te $n=15$; female: Te1 $n=14 ;$ Te3 $n=20$

* Statistically significant difference

SD: Standard deviation 
group, but they showed no difference in height, either at Te1 or Te2. For women, there were no significant differences in weight, height and BMI between the group with sickle-cell anaemia and the control group at Te1. However, at Te3, women from the group with sickle-cell anaemia had significantly lower weight and BMI than their controls (c.f. Table 2).

Evaluating the anthropometric parameters only in the group of patients with sickle-cell anaemia and com- paring by sex, it was found that men had greater weight commintent than women at the three study times, and a lower BMI in adulthood (c.f. Table 3).

Evaluating the evolution of anthropometric variables of the sickle-cell anaemia group, it was observed that their Z-score averages increased steadily over the years, with significant weight gain comparing Te1 and Te3 and height comparing Te1 with Te2 and Te3 (c.f. Table 4).

Table 3: Comparison of anthropometric variables between men and women with sickle cell disease (cases) in the three study times

\begin{tabular}{|c|c|c|c|c|}
\hline & STUDY TIMES & $\begin{array}{c}\text { MALE } \\
\text { MEAN } \pm \text { SD }\end{array}$ & $\begin{array}{c}\text { FEMALE } \\
\text { MEAN } \pm S D\end{array}$ & $\mathbf{P}$ \\
\hline & Te1 & $14.25 \pm 3.29$ & $13.57 \pm 3.50$ & 0.394 \\
\hline \multirow[t]{2}{*}{ Age (years) } & $\mathrm{Te} 2$ & $20.13 \pm 3.06$ & $20.00 \pm 3.55$ & 0.6625 \\
\hline & $\mathrm{Te} 3$ & $24.77 \pm 2.28$ & $25.38 \pm 3.30$ & 0.8576 \\
\hline Weight for age & Te1 & $-1.69 \pm 0.40$ & $-1.20 \pm 0.61$ & $0.0340^{*}$ \\
\hline \multirow[t]{2}{*}{ Z-score } & $\mathrm{Te} 2$ & $-1.39 \pm 0.72$ & $-0.86 \pm 0.64$ & $0.0426^{*}$ \\
\hline & $\mathrm{Te} 3$ & $-1.08 \pm 0.59$ & $-062 \pm 0.60$ & $0.0387^{*}$ \\
\hline Height for age & Te1 & $-1.66 \pm 1.21$ & $-1.20 \pm 1.13$ & 0.2616 \\
\hline \multirow[t]{2}{*}{ Z-score } & $\mathrm{Te} 2$ & $-0.65 \pm 0.80$ & $-0.57 \pm 1.17$ & 0.9753 \\
\hline & $\mathrm{Te} 3$ & $-0.36 \pm 0.86$ & $-0.46 \pm 1.22$ & 1.0000 \\
\hline BMI for age & $\mathrm{Te} 1$ & $-1.85 \pm 1.30$ & $-1.16 \pm 1.43$ & 0.1142 \\
\hline \multirow[t]{2}{*}{ Z-score } & $\mathrm{Te} 2$ & $-1.69 \pm 1.32$ & $-0.92 \pm 1.37$ & 0.1366 \\
\hline & $\mathrm{Te} 3$ & $-1.12 \pm 0.78$ & $-0.14 \pm 1.01$ & $0.0155^{*}$ \\
\hline
\end{tabular}

Study times: Te1: 2005; Te2: 2010; Te3: 2015

* Statistically significant difference

SD: Standard deviation

Table 4: Anthropometric variables of patients with sickle cell disease in the three study times

\begin{tabular}{|c|c|c|c|c|c|}
\hline & STUDY TIMES & MEAN $\pm S D$ & $\mathbf{p}$ & $\begin{array}{l}\text { COMPARISON } \\
\text { BETWEEN } \\
\text { THE STUDY } \\
\text { TIMES }\end{array}$ & $\mathbf{p}$ \\
\hline \multirow[t]{3}{*}{ Weight for age Z-score } & Te1 & $-1.46 \pm 0.56$ & & $\mathrm{Te} 1 \times \mathrm{Te} 2$ & 0.0972 \\
\hline & $\mathrm{Te} 2$ & $-1.14 \pm 0.72$ & 0.0041 & $\mathrm{Te} 1 \times \mathrm{Te} 3$ & $0.009^{*}$ \\
\hline & $\mathrm{Te} 3$ & $-0.86 \pm 0.62$ & & $\mathrm{Te} 2 \times \mathrm{Te} 3$ & 0.1307 \\
\hline \multirow[t]{3}{*}{ Height for age Z-score } & $\mathrm{Te} 1$ & $-1.44 \pm 1.17$ & & $\mathrm{Te} 1 \times \mathrm{Te} 2$ & $0.0292^{*}$ \\
\hline & $\mathrm{Te} 2$ & $-0.61 \pm 0.96$ & 0.0012 & $\mathrm{Te} 1 \times \mathrm{Te} 3$ & $0.0003^{*}$ \\
\hline & $\mathrm{Te} 3$ & $-0.41 \pm 1.03$ & & $\mathrm{Te} 2 \times \mathrm{Te} 3$ & 0.2082 \\
\hline \multirow[t]{3}{*}{ BMI for age Z-score } & Te1 & $-1.53 \pm 1.38$ & & $\mathrm{Te} 1 \times \mathrm{Te} 2$ & \\
\hline & $\mathrm{Te} 2$ & $-1.35 \pm 1.38$ & 0.1034 & $\mathrm{Te} 1 \times \mathrm{Te} 3$ & \\
\hline & $\mathrm{Te} 3$ & $-0.65 \pm 1.01$ & & $\mathrm{Te} 2 \times \mathrm{Te} 3$ & \\
\hline
\end{tabular}

Study times: Te1: 2005; Te2: 2010; Te3: 2015

* $\quad$ Statistically significant difference

SD: Standard deviation

At Te1, 14 cases $(46.7 \%)$ and 2 controls $(6.66 \%)$ were classified as prepubertal. Bone age was delayed in 12 patients $(46.15 \%)$. Age of menarche was delayed in the sickle-cell anaemiagroup (mean= 15 years), with a statistically significant difference between the groups (c.f. Table 5). Five patients had gestated, but no patient had experienced parenthood, and spontaneous abortion had occurred in two patients.

The sickle-cell anaemiagroup had significantly higher mean TSH levels than the the control at Te1, but only three patients $(10 \%)$ were diagnosed with subclinical hypothyroidism and no cases of clinical hypothyroidism were observed. FT4 levels were similar in the two groups in two periods whilst T3 levels were significantly lower in cases at Te1. Anti-thyroid peroxidase antibody was positive in three patients in the sickle-cell anaemia group and in one control (c.f. Table 5). Subclinical hypothyroidism was observed in one patient with sickle-cell anaemia in adulthood, who had positive anti-TPO and had presented normal levels of thyroid hormones in the past.

At Te1, baseline levels of gonadotropins and sex steroids in men and women were evaluated and a trend 
Table 5: Data on bone age, puberty, age of menarche and hormone levels in patients with sickle cell disease (cases) and their respective healthy controls (controls) in Te1 and Te3 study times

\begin{tabular}{|c|c|c|c|c|c|c|}
\hline & $\begin{array}{c}\text { Cases in } \\
\text { Te1 } \\
\text { MEAN } \pm \text { SD }\end{array}$ & $\begin{array}{c}\text { Controls in } \\
\text { Te1 } \\
\text { MEAN } \pm \text { SD }\end{array}$ & $\mathbf{p}$ & $\begin{array}{c}\text { Cases in } \\
\text { Te3 } \\
\text { MEAN } \pm \text { SD }\end{array}$ & $\begin{array}{c}\text { Controls in } \\
\text { Te3 } \\
\text { MEAN } \pm \text { SD }\end{array}$ & p \\
\hline Age (years) & $13.93 \pm 3.35$ & $14.20 \pm 2.63$ & 0.3516 & $25.08 \pm 2.80$ & $25.40 \pm 2.84$ & 0.7483 \\
\hline $\begin{array}{l}\text { Bone age } \\
\text { (years) }\end{array}$ & $\begin{array}{c}11.58 \pm 3.40 \\
(8 \text { a } 23)\end{array}$ & & & & & \\
\hline Impuberes $\mathrm{N}$ & $(46.66 \%)$ & $2 / 30$ & & & & \\
\hline$(\%)$ & $14 / 30$ & $(6.66 \%)$ & & & & \\
\hline $\begin{array}{l}\text { Age of menarche } \\
\text { (years) }\end{array}$ & & & & $\begin{array}{c}15.00 \pm 1.41 \\
(n=13)\end{array}$ & $\begin{array}{c}12.45 \pm 1.15 \\
(n=20)\end{array}$ & $0.0002^{*}$ \\
\hline T3 (ng/dl) & $1.40 \pm 0.21$ & $1.58 \pm 0.24$ & $0.0020^{*}$ & $1.11 \pm 0.31$ & $1.09 \pm 0.18$ & 0.9129 \\
\hline FT4 (ng/dl) & $1.07 \pm 0.24$ & $1.07 \pm 0.13$ & 0.3255 & $1.27 \pm 1.25$ & $1.06 \pm 0.12$ & 0.6094 \\
\hline TSH (uUl/ml) & $3.03 \pm 1.49$ & $2.13 \pm 1.09$ & $0.0080^{*}$ & $2.09 \pm 1.32$ & $1.43 \pm 0.61$ & 0.1257 \\
\hline Anti-TPO + N (\%) & & & & $3 / 25(12 \%)$ & $1 / 35(2.8 \%)$ & \\
\hline FSH (mUi/ml) & $3.44 \pm 2.27$ & $3.43 \pm 1.88$ & 0.6256 & $7.12 \pm 4.49$ & $2.09 \pm 1.07$ & $0.0002^{*}$ \\
\hline LH (mUi/ml) & $4.44 \pm 7.34$ & $3.21 \pm 3.56$ & 0.4132 & $6.34 \pm 2.90$ & $3.33 \pm 1.46$ & $0.0014^{*}$ \\
\hline Prolactin (ng/ml) & $6.68 \pm 4.79$ & $8.48 \pm 3.90$ & $0.0141^{*}$ & $16.03 \pm 10.53$ & $13.73 \pm 4.99$ & 0.7529 \\
\hline Estradiol (pg/ml) & $47.15 \pm 51.74$ & $54.67 \pm 42.56$ & 0.3581 & & & \\
\hline Testosterone (ng/ml) & $1.28 \pm 2.03$ & $2.76 \pm 2.45$ & 0.0595 & $7.58 \pm 3.43$ & $6.98 \pm 2.50$ & 0.6784 \\
\hline IGF-1 (ng/ml) & $162.7 \pm 100.92$ & $390.7 \pm 229.60$ & $0.0002^{*}$ & $133.95 \pm 50.48$ & $186.64 \pm 66.34$ & $0.0032^{*}$ \\
\hline
\end{tabular}

Study times: Te1: 2005; Te2: 2010; Te3: 2015

T3: Triiodothyronine; FT4: free thyroxine; TSH: thyroid stimulating hormone; Anti-TPO: anti-thyroid peroxidase antibody; FSH: follicle stimulating hormone; LH: luteinizing hormone; IGF-1: Insulin-like growth factor 1 (IGF-1) or somatomedin C.

* Statistically significant difference.

SD: Standard deviation.

of lower testosterone levels among men in the sickle-cell anaemia group was observed. At Te3, this evaluation was carried out only in men, because most women in both groups were using contraceptives, which would influence the evaluation of the pituitary-gonadal axis. There was no statistically significant difference in testosterone levels between adult men groups, while LH and FSH levels were significantly higher in men with sickle- cell diesease than in controls. IGF-I levels were significantly lower in cases than in controls at Te1 and Te3 (c.f. Table 5).

\section{DISCUSSION}

Sickle-cellanaemia is the second biggest cause of anaemia and is the most frequent monogenetic disease in Brazil and in countries around the world, thereby making it a significant public health problem. Manifesting itself very early in childhood, and evolving chronically throughout life, its impact on growth is controversial in some aspects. This study, in an original way, presents the results of evaluation of growth obtained longitudinally over ten years, thereby avoiding the weaknesses arising from the comparison of results from cross-sectional studies in different age groups. We analysed prospectively the growth and associated factors in a group of sickle-cell anaemia patients from the onset of puberty to adulthood, showing recovery of height impairment in adulthood, but no recovery for weight and BMI.

The impaired growth in sickle-cell anaemiapatients is multifactorial, with possible determinants related to own pathophysiology of the disease, such as chronic anaemia, increased metabolism due to hyperactivity of the bone marrow and chronic inflammation, and other factors, such as malnutrition and endocrine dysfunction ${ }^{14}$. The results of this study indicate that children and adolescents with sickle-cell anaemia have lower weight, height and BMI than their healthy peers, as previously reported ${ }^{15}$. It has been observed that adults with sickle-cell anaemia had lower weight and BMI than their controls, but showed no difference in height, and therefore there is greater height recovery compared to weight.

The possibility of patients with sickle-cell anaemia reaching their target height in adulthood is controversial in the literature. The findings of this study corroborate previous studies that reported lower stature than healthy controls in young and normal stature in adults with sickle-cell anaemia ${ }^{7,15,16}$. Other studies have however observed that children with sickle-cell anaemia did not reach normal height as adults ${ }^{4,16,17}$. The frequency and severity of injuries resulting from sickle-cell anaemia, as well as the interference of environmental issues, can impact negatively on growth. Thus, more consistent answers regarding the recovery of the growth delay in patients with sickle-cell anaemia in adulthood can be obtained from prospective longitudinal studies.

It was observed that boys showed significant deficits compared to the control group in weight and BMI in childhood, adolescence and adulthood, whilst no difference in stature between groups was detected. Furthermore, data obtained from the girls showed no significant difference in weight, height and BMI compared with the control group during childhood and adolescence (Te1), but weight and BMI were significantly lower than in the control group in adulthood (Te3). These data indicate a trend that weight impairment in patients with sickle-cell anaemia can already be observed in males during childhood and adolescence, but it only affects women at the start of adulthood.

Weight impairment in patients with sickle-cell anaemia was more intense in males during the three stages 
of the study. This finding is not a consensus in the literature ${ }^{4,16,18}$. In this study, based on the Z-scores for weight, height and BMI according to age and gender, the results for the patients with sickle-cell anaemia have gradually become similar to those of healthy individuals. However, although there was a significant increase in weight between $\mathrm{Te} 1$ and $\mathrm{Te} 3$, there was a greater recovery of final height than weight, as reported in the literature ${ }^{16}$.

Delay in skeletal maturation with delayed bone age in the sickle-cell anaemia group was observed in the present study. Patients had a mean chronological age of $13.93 \pm 3.35$ years (10-23 years) and an average bone age of $11.32 \pm 2.82$ years ( $8-18$ years) and these findings are comparable to other studies ${ }^{15}$. Delayed puberty occurred in $46.66 \%$ of patients with sickle-cell anaemia and $6.66 \%$ of the controls. This finding is in line with previous studies showing that patients reached normal sexual maturation, although later ${ }^{4,18}$. There was a statistically significant difference between the groups regarding the age of menarche, averaging 15 years in the sickle-cell anaemia group and 12.45 years in the control group. A previous study showed that $56.2 \%$ of Brazilian girls at the age of 14 with sickle-cell anaemia had not reached menarche and the average age of menarche was 15 years, while in the control group it was 13 years ${ }^{7}$. Another Brazilian study found that only four out of 16 girls over the age of ten with sickle-cell anaemia had presented menarche, which occurred at an average age of 15 years and 8 months $^{4}$. The results of this study, therefore, confirm the delay in age at menarche among girls with sickle-cell anaemia.

Adolescents with sickle-cell anaemia showed a delay in the onset of pubertal growth spurt and in the ages of peak growth rate when compared to their healthy peers $^{16}$. The pubertal delay associated with bone age delay, followed by abnormal delay of epiphyseal fusion during puberty, allows the growth of long bones for a variable period of time in early adulthood, thereby explaining the paradoxical relationship between delayed prepubertal growth and standard height in adulthood ${ }^{19}$.

IGF-1 levels in children and adolescents with sickle-cell anaemia at Te1 were significantly lower than those of the control group, which matches the pubertal delay presented by the group and is in accordance with previous finding $\mathrm{s}^{20}$. Change in the GH-IGF-1 axis was considered an etiological factor, playing an important role in the impaired growth in children with sickle-cell anaemia ${ }^{21}$. IGF1 levels in patients with sickle-cell anaemia evaluated in adulthood remained significantly lower than the levels in the control group, although patients had reached normal height. The lower BMI in adults with sickle-cell anaemia, due to the low weight, may explain the reduced IGF-1 levels ${ }^{22}$.

The pituitary-gonadal evaluation showed no difference in baseline-level gonadotropins at Te1, or estradiol in women, but a trend of reduced basal levels of testosterone in boys with sickle-cell anaemia compared to controls was observed, which is reflected in the pubertal delay. As adults, men with sickle-cell anaemia had significantly higher mean LH and FSH levels than controls and similar testosterone levels. These results contrast with the literature, since studies have shown low testosterone in adult men with sickle-cell anaemia, with gonadotropin levels that may reflect both hypogonadotropic hypogonadism and as hypergonadotropic ${ }^{2,23}$. A previous study found significantly lower testosterone averages in the sickle-cell anaemia group than in controls, but with similar averages of LH and FSH24. The prolactin levels, in this study, showed no statistical difference between the groups in adulthood, in accordance with a previous study ${ }^{24}$. The averages of gonadotropin are higher in patients with sickle-cell anaemia in this study, which may be due to the pubertal delay, leading to a pattern of stimulation of the pituitary-gonadal axis ${ }^{25}$.

The obstetric history of the women with sickle-cell anaemia revealed that five of the 14 patients had gestated, two of whom had miscarried. A previous study evaluated the regularity of cycles and ovulatory pattern in young women with sickle-cell anaemia in the same service and showed that the reproductive capacity is preserved ${ }^{26}$. Although in this study, any intention of paternity has not been directly investigated, no young adult with sickle-cell anaemia in this sample, with normal testosterone levels in the group, has experienced paternity, thereby highlighting the need to investigate aspects related to male fertility. Men with sickle-cell anaemia may have fertility issues related to quantitative and/or qualitative changes in semen, or sexual problems, such as impotence, priapism and frequent episodes of premature ejaculation as previously reported ${ }^{27}$. The literature reports that infertility seems to be a bigger problem among men than among women with sickle-cell anaemia ${ }^{14}$.

The study of thyroid function at Te1 showed higher levels of TSH and reduced T3 in the group of children and adolescents with sickle-cell anaemia, and subclinical hypothyroidism in three patients, which evolved with normal thyroid function. In adulthood, there was no statistical difference in the levels of thyroid hormones and a single case of subclinical hypothyroidism was shown, with anti-TPO positive. The results corroborate previous findings of a significant reduction of T3 and TSH elevation in men with sickle-cell anaemiacompared to controls $^{28}$. No case of clinical hypothyroidism in this population was observed. The low prevalence of hypothyroidism in sickle- cell diesease was reported in previous studies ${ }^{2,29}$.

One limitation of this study was the sample size, resulting from the need to exclude patients who received regular blood transfusions and who had frequent complications. Other limitations are the lack of assessment of bone age in the control group and not carrying out systematic nutritional assessment in both groups.

Patients with sickle-cell anaemia in this study exhibited growth impairment and pubertal delay when compared to healthy controls. However, albeit belatedly, they reached normal sexual maturation. Moreover, they reached normal height in adulthood, in contrast to weight and BMI, with even stronger evidence in males. Levels of IGF-1 were persistently lower even in adulthood and after height recovery were observed. The evaluation of the pituitary-gonadal axis showed conflicting results in relation to the literature. It was also observed that the women with sickle-cell anaemia did not mention difficulties related to fertility. 


\section{REFERENCES}

1. Weatherall DJ. The inherited diseases of hemoglobin are an emerging global health burden. Blood 2010;115(22):4331-6. DOI: http://dx.doi.org/10.1182/blood-2010-01-251348

2. Ozen S, Unal S, Erçetin N, Taşdelen B. Frequency and risk factors of endocrine complications in Turkish children and adolescents with sickle cell anemia. Turkish J Haematol. 2013;30(1):25-31. DOI: http://dx.doi. org/10.4274/tjh.2012.0001

3. Al-Saqladi AW, Bin-Gadeen HA, Brabin BJ. Growth in children and adolescents with sickle cell disease in Yemen. Ann Trop Paediatr 2010;30(4):287-98. DOI: http://dx.doi.org/10.1179/146532810X12858955921113

4. Cipolotti R, Caskey MF, Franco RP, Mello EV, Dal Fabbro AL, Gurgel RQ, et al. Childhood and adolescentes growth of patient with sickle cell disease in Aracaju. Ann Trop Paediatr. 2000;20(2):109-13. DOI: http:// dx.doi.org/10.1080/02724930050043407

5. Singhal A, Thomas P, Cook R, Wierenga K, Serjeant G. Delayed adolescent growth in homozygous sickle cell disease. Arch Dis Child. 1994;71(5):404-8.

6. Serjeant GR, Singhal A, Hambleton IR. Sickle cell disease and age at menarche in Jamaican girls: observations from a cohort study. Arch Dis Child 2001;85(5):375-8.

7. Zago MA, Costa FF, Tone LG, Bottura C. Hereditary hemoglobin disorders in a Brazilian population. Hum Hered. 1983;33:125-9.

8. Zemel BS, Kawchak D a, Ohene-Frempong K, Schall JI, Stallings V a. Effects of delayed pubertal development, nutritional status, and disease severity on longitudinal patterns of growth failure in children with sickle cell disease. Pediatr Res. 2007;61(5):607-13. DOI: http://dx.doi.org/10.1203/pdr.0b013e318045bdca

9. Kuczmarski RJ, Ogden CL, Guo SS, Grummer-Strawn LM, Flegal KM, Mei Z, et al. 2000 CDC Growth Charts for the United States: Methods and Development. Vital Heal Stat. 2002; (246):1-190.

10. Onis M, Onyango AW, Borghi E, Siyam A, Nishida C, Siekmann J. Development of a WHO growth reference for school-aged children and adolescents. Bull World Health Organ. 2007;85(9):660-7. ,

11. Marshall WA, Tanner JM. Variations in pattern of pubertal changes in girls. Arch Dis Child. 1969; 44(235): 291-303.

12. Marshall WA, Tanner JM. Variations in the pattern of pubertal changes in boys. Arch Dis Child. 1970;45(239):13-23.

13. Greulich WW, Pyles SI. Radiographic atlas of skeletal development of the hand and wrist. 2. ed. Stanford: Stanford University Press; 1959; p. 255.

14. Smiley D, Dagogo-Jack S, Umpierrez G. Therapy insight: metabolic and endocrine disorders in sickle cell disease. Nat Clin Pract Endocrinol Metab 2008;4(2):102-9. DOI: http://dx.doi.org/10.1038/ncpendmet0702

15. Ashcroft MT, Serjeant GR, Desai P. Height, weight and skeletal age of Jamaican and adolescentes with sickle cell disease. Arch Dis Child 1972;47(254):519-24.

16. Singhal A, Thomas P, Cook R, Wierenga K, Serjeant G. Delayed adolescent growth in homozygous sickle cell disease. Arch Dis Child. 1994;71(5):404-8. ,

17. Henderson RA, Saavedra JM, Dover GJ. Prevalence of impaired growth in children with homozygous sickle cell anemia. Am J Med Sci. 1994;30796):405-7. DOI: http://dx.doi.org/10.1097/00000441-19940600000004

18. Zago MA, Kerbauy J, Souza HM, Figueiredo MS, Costa FF, Cruz SM, et al. Growth and sexual maturation of Brazilian patients with sickle cell diseases. Trop Geogr Med. 1992; 44(4):317-21.

19. Veríssimo MPA. Crescimento e desenvolvimento nas doenças falciformes. Rev Bras Hematol Hemoter. 2007;39(3):271-4. DOI: http://dx.doi.org/10.1590/S1516-84842007000300015

20. Collett-Solberg PF, Fleenor D, Schultz WH, Ware RE. Short stature in children with sickle cell anemia correlates with alterations in the IGF-I axis. J Pediatr Endocrinol Metab. 2007;20(2):211-8. DOI: http://dx.doi. org/10.1515/JPEM.2007.20.2.211

21. Soliman AT, EI Banna N, AI Salmi I, De Silva V, Craig A, Asfour M. Growth hormone secretion and circulating insulin-like growth factor-I (IGF-I) and IGF binding protein-3 concentrations in children with sickle cell disease. Metabolism. 1997;46(11):1241-5. DOI: http://dx.doi.org/10.1016/S0026-0495(97)90224-9

22. Yamamoto H, Yuzuru K. Relationship between plasma insulin-like growth factor I (IGF-I) levels and body mass index (BMI) in adults. Endocr J. 1993;40(1):41-5. DOI: http://dx.doi.org/10.1507/endocrj.40.41

23. Taddesse A, Woldie IL, Khana P, Swerdlow PS, Chu J, Abrams J, et al. Hypogonadism in Patients with Sickle Cell Disease: Central or Peripheral? Acta haematologica 2012;128(2): 65-8. DOI: http://dx.doi. org/10.1159/000337344

24. Modebe O, Ezeh UO. Effect of age on testicular function in adult males with sickle cell anemia. Fertil Steril 1995;63(4):907-12. DOI: http://dx.doi.org/10.1016/S0015-0282(16)57500-1

25. Lee PA, Migeon CJ. Puberty in boys: correlation of plasma levels of gonadotropins (LH, FSH), androgens (testosterone, androstenedione, dehydroepiandrosterone and its sulfate), estrogens (estrone and estradiol) and progestins (progesterone and 17-hydroxyprogesterone). J Clin Endocrinol Metab. 1975;41(3):55662. DOI: http://dx.doi.org/10.1210/jcem-41-3-556 
26. Viana Junior JW, Felix WO, Cipolotti R. Regularidade de ciclos e padrão ovulatório em jovens portadoras de anemia falciforme. Rev Bras Ginecol Obstet. 2010;32(11):3-7. DOI: http://dx.doi.org/10.1590/S010072032010001100002

27. Osegbe DN, Akinyanju O, Amaku EO. Fertility in male with sickle cell disease. Lancet. 1981;2(8241):2756. DOI: http://dx.doi.org/10.1016/S0140-6736(81)90525-0

28. Parshad O, Stevens MC, Hudson C, Rosenthal J, Melville GN, Dunn DT, et al. Abnormal thyroid hormone and thyrotropin levels in homozygous sickle cell disease. Clin Lab Haematol. 1989;1194):309-15. DOI: http://dx.doi.org/10.1111/j.1365-2257.1989.tb00228.x

29. Phillips G, Becker B, Keller VA. Hypothyroidism in adults with sickle-cell anemia. Am J Med. 1992; 92(5): 567-70. DOI: http://dx.doi.org/10.1016/0002-9343(92)90757-3

This article is distributed under the terms of the Creative Commons Attribution 4.0 International License (http://creativecommons.org/licenses/by/4.0/), which permits unrestricted use, distribution, and reproduction in any medium, provided you give appropriate credit to the original author(s) and the source, provide a link to the Creative Commons license, and indicate if changes were made. The Creative Commons Public Domain Dedication waiver (http://creativecommons.org/publicdomain/zero/1.0/) applies to the data made available in this article, unless otherwise stated.

\section{Resumo}

Introdução: Hemoglobinopatias hereditárias são o grupo das doenças hereditárias monogênicas mais frequentes no mundo. Os eritrócitos na forma de foice, expressão celular da polimerização da $\mathrm{He}-$ moglobina $S$ desoxigenada, causam obstrução vascular intermitente, levando à isquemia tecidual $\mathrm{e}$ consequente dano crônico em órgãos e glândulas endócrinas.

Objetivo: Avaliar o padrão de crescimento e desenvolvimento puberal de um grupo de portadores de anemia falciforme desde a infância até a vida adulta.

Método: Trinta pacientes com anemia falciforme entre 10 e 23 anos foram avaliados de forma longitudinal prospectiva em três tempos (Te1: 2005, Te2: 2010 e Te3: 2015) comparativamente a controles. Foram realizadas avaliações antropométrica, puberal e hormonal. Z-escores de peso, estatura e índice de massa corpórea para idade e sexo foram calculados através da comparação com padrões de referência. Resultados: Em Te1, foram avaliados 30 pacientes com média de idade de 13,93 anos; em Te3, 26 pacientes com média de 25,08 anos. Os controles tiveram média de idade e proporção de sexo similares ao grupo anemia falciforme. Em Te1, o grupo anemia falciforme apresentou Z-escores de peso (p: 0,0002); estatura (p: 0,0184) e IMC (p: 0,0011) menores que o grupo controle. Em Te3, não houve diferença quanto à estatura, mas peso $(p:<0,0001)$ e índice de massa corpórea $(p:<0,0001)$ foram menores no grupo anemia falciforme. Os homens apresentaram maior comprometimento ponderal em relação às mulheres nos três tempos ( $\mathrm{Te} 1$ p: 0,0340, Te2 p: 0,0426 e Te3 p: 0,0387) e menor índice de massa corpórea em Te3 ( $p: 0,0155$ ). Nogrupoanemiafalciformehouveaumentosignificativo depesoquandocomparados Te 1 eTe3 ( $p: 0,0009$ ) e da estatura quando comparado Te1 ao Te2 ( $p: 0,0292$ ) e ao Te3 (p: 0,0003). Em Te1, 14 casos e 2 controles foram considerados impúberes. Idade óssea foi atrasada em 12 pacientes. Idade da menarca foi maior no grupo anemia falciforme (média $=15$ anos). Cinco pacientes já haviam gestado, porém nenhum paciente havia experimentado a paternidade. Em Te1, níveis de TSH foram maiores ( $p: 0.0080$ ) e de T3 menores ( $p: 0.0020$ ) no grupo anemia falciforme. Em Te3, os níveis de LH e FSH foram maiores nos homens com anemia falciforme ( $p$ : $0.0014 ; p ; 0.0002)$. Níveis de IGF-1 foram menores nos casos em Te1 ( $p: 0.0002)$ e Te3 (p: 0.0032).

Conclusão: Pacientes com anemia falciforme apresentaram comprometimento de crescimento e atraso puberal quando comparados a controles. Todavia, ainda que tardiamente, atingem maturação sexual normal. Além disso, alcançaram estatura normal na idade adulta, diferentemente do que ocorreu com peso e índice de massa corpórea. As mulheres com anemia falciforme não relataram dificuldade em relação à fertilidade.

Palavras-chave: anemia falciforme, estudos prospectivos, crescimento, puberdade. 